\title{
Cervical Cancer cT3a TNM Finding v8
}

National Cancer Institute

\section{Source}

National Cancer Institute. Cervical Cancer CT3a TNM Finding v8. NCI Thesaurus. Code C139700.

Cervical cancer involving the lower third of vagina but not extending to pelvic wall. (from AJCC 8th Ed.) 